\title{
菱田 元 $^{1}$ 蘕 部 保 德 ${ }^{3}$
}

\section{Development and Application of Mineral Exploration Technique}

\author{
by Hajime HISHIDA ${ }^{\mathrm{a} *}$, Takashi OOKA ${ }^{\mathrm{a}}$ and Yasunori NUIBE ${ }^{\mathrm{b}}$
}

a. Japan Oil, Gas and Metals National Corporation (JOGMEC)

(*Corresponding author: E-mail hishida-hajime@jogmec.go.jp)

b. JOGMEC (Nittetsu Mining Co.Ltd. , at Present)

This paper reviews the development of remote sensing, geophysical and geochemical techniques, and their application to mineral exploration over the last decade in addition to introducing the related research and development works by the Metal Mining Agency of Japan (presently Japan Oil, Gas and Metals National Corporation). In the field of geologic remote sensing, ASTER data with high spatial and spectral resolutions is widely used as well as conventional satellite data such as LANDSAT and SPOT data. Airborne data acquisition with either optical or radar sensor is commonly used. Hyper spectral data acquisition has also been developed both in satellite and airborne systems. Geophysical techniques are versatile using airborne, ground and drill-hole methods. In gravity, magnetic, electric and electromagnetic methods, several techniques have been developed in data acquisition and analysis. Airborne gravity method has been recently developed and started to be used in exploration. Though the geochemical techniques are still based on conventional methods employing rocks, soils and stream sediments, better understanding to the geochemical phenomenon has greatly improved interpretation of the results. Regolith mapping method, which was resulted from research work for the deeply weathered tropical terrain, is one of the good examples. Exploration manager is required to follow the more advanced mineral exploration techniques and apply the most suitable combination of the methods to the project in response to the exploration stage.

KEYWORDS: Mineral Exploration, Remote Sensing, Geophysical Exploration, Geochemical Exploration

\section{1.はじめに}

鉱床は奥地化・潜頭化し，新鉱床を発見することはますます困 難になってきている。鉱床は多様な型を持ち, それを胚胎する地 質構造もさまざまであるため, 鉱床探査の新しい技術が開発され ても, それが適用可能か否かは適切なケーススタディを積まない と判断できない。鉱床探查の柱となるのは地質調查とその解釈で あるが，ここではそれを補足する探查技術であるリモートセンシ ング, 物理探査, 地化学探査について, 技術開発状況とその適用 を金属鉱業事業団 (2004 年 2 月 29 日付けで独立行政法人 石油天 然ガス・金属釷物資源機構に組織変更) の取り組みも交え紹介寸 る。なお，探査技術の重要な要素であるボーリング技術について は，筆者らの専門外であり省略した。

$$
\text { 2. リモートセンシング }
$$

\footnotetext{
*2004 年 7 月 30 日受付 2004 年 11 月 10 日受理

1. 普通会員 石油天然ガス・金属鉱物資源機構 業務評価・審査グループ 調査役

2. 石油天然ガス・金属鉱物資源機構 業務評価・審査グループ チームリーダー

3. 石油天然ガス・金属釷物資源機構 (現 日鉄釷業(株) 資源開発部)

[ 著者連絡先 ] FAX : 044-520-8710 (菱田)

E-mail: hishida-hajime@jogmec.go.jp

キーワード : 鉱床探査, リモートセンシング, 物理探査, 地化学探査
}

鉱床探査の初期段階にとって衛星リモートセンシング・データ は欠かせないものであり, 新しい地域の調查を始める場合は, ま ず有効と思われる衛星画像を入手するのが常である。一方, 航空 機リモートセンシングの需要も近年増えてきており，センサー技 術開発の一環として衛星搭載前に航空機に搭載して試験する場合 も多い。リモートセンシング技術の開発はセンサー開発から適用 技術まで非常に幅広いが，ここでは鉱床探査という視点から全体 を概観する。

$2 \cdot 1$ 衛星リモートセンシング

$2 \cdot 1 \cdot 1$ 光学センサー 資源探查分野における衛星りモー トセンシングの利用は, 1970 年代から稼働の始まった米国の地 球観測衛星 LANDSATにより実質的に幕を開けた。初期の LANDSAT-1 〜 3 には可視・近赤外域に $3 \sim 4$ バンドを持つ光学 センサー (MSS) が搭載され, これを利用して写真地質学的な解 析を行った。その後に打ち上げられた LANDSAT-4, -5 (1982 年, 1984 年) には, 空間分解能を高め, 短波長赤外域にもバンドを 増強したより高性能の TM センサーが搭載された。これにより多 くの鉱物・岩石特有のスペクトル特徵を捕捉できるようになり, 地質解析に大きな進展をもたらした。現在では TM センサーをさ らに向上させた ETM+センサーが稼働している (LANDSAT-7： 2003 年 5 月にセンサーの不具合が発生し, 正常な運用が中断さ れている)。米国以外ではフランスが 1986 年から高分解能の 
SPOT 衛星シリーズを稼働させており，LANDSAT と SPOT が国 際標準として認知されている1)。

我が国独自の地球観測衛星としては，資源探査を主目的とした JERS-1 (ふよう 1 号) が 1992 年に打ち上げられ，可視近赤外域 と短波長赤外域で全 7 バンドを持つ光学センサー (OPS) と合成開 ロレーダー (SAR) のデータの利用が開始された。1999 年には我 が国が開発した ASTER センサーを搭載した米国の地球観測衛星 TERRA が打ち上げられた。ASTER センサーは可視光から熱赤外 波長域 $(0.52 \sim 11.65 \mu \mathrm{m})$ において全 14 バンドを有する高性能光 学センサーで，熱赤外多バンドセンサーを搭載していること，立 体視が可能なバンドも備えており高精度の DEM が作成できるこ と，などの特長を有する。

一方, 光学センサーの多バンド化は，200バンドを超える光学 超多バンド (ハイパースペクトル) センサーへと開発が進んでき ており, より高精度なスペクトルの解析技術が求められている。 金属鉱業事業団でも 2001 年度より「超多バンド光学センサー技 術の開発」を開始している。また，米国 Space Imaging 社の IKONOS に代表される商用ベースで $1 \mathrm{~m}$ の高空間分解能を持つ衛 星データの利用も始まっている。

$2 \cdot 1 \cdot 2$ マイクロ波センサー マイクロ波を利用した(合 成開ロレーダー等) の開発は 1970 年代後半から進んできており, 特に欧州宇宙機構の ERS シリーズ (1991 年〜) や我が国の JERS-1 (1992 年), カナダの RADARSAT シリーズ (1995 年〜) 等の合成開ロレーダー (SAR) 等によりデータが利用できるよう になった。波長数 $\mathrm{cm}$ から $30 \mathrm{~cm}$ 程度のマイクロ波 $(\mathrm{C} \sim \mathrm{L}$ バンド $)$ により，雲，雨等の影響を受けないで高精度の地形情報が取得す ることが可能になる。我が国でも JERS-1 等の合成開ロレーダー を利用して地形情報から鉱物資源の胚胎可能性を追跡する研究が 政府関係機関，大学，資源関連会社等を中心に行われている。そ の他近年では，レーダーから複数の偏波情報を送受信することで 地表物質識別や含水状態などの物性の違いを明らかにしようとす

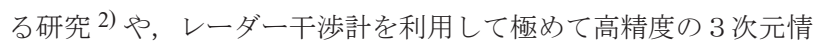
報あるいは地表変位情報等を取得寸る研究も進展してきている3)。 金属鉱業事業団でも 2001 年度より多編波情報を利用した「高精 度合成開口レーダー解析技術の開発」を開始している。

\section{$2 \cdot 2$ 航空機リモートセンシング}

$2 \cdot 2 \cdot 1$ 光学センサー 初期の航空機リモートセンシン グは白黒の空中写真を利用した地質判読にすぎなかったが，その 後, 各種衛星センサーに先行する形でより高度な航空機センサー の開発と利用が進められてきた。ハイパースペクトルについては 1970 年代後半から開発が進み，1990 年代以降商用システムが運 用されている。特に米国 NASA/JPL の AVIRIS (224 バンド : 0.38 $\sim 2.5 \mu \mathrm{m})$ は改良が重衫られ，信頼性が高く多くの研究で利用さ れている。また，豪州でも八イパースペクトルの研究が盛んであ り, HyMap (128 バンド : $0.45 \sim 2.48 \mu \mathrm{m})$ 等が開発・利用されて いる。金属鉱業事業団も $2001 \sim 2002$ 年度に VMS 鉱床に関係す るゴッザン抽出に HyMap データを試用した ${ }^{4)}$ 。

熱赤外センサーではNASAの TIMS，Aeospace 社の SEBASS， 豪州 CSIRO 等で開発した ARGUS (TIPS モジュール) 等が代表的 で, これらを利用して珪酸塩岩の識別等の研究が行われている。

$2 \cdot 2 \cdot 2$ マイクロ波センサー＼cjkstart航空機搭載型のマイクロ 波センサーは1960年代後半の Side-Looking Airborne Radar（SLAR） から主に利用が開始され，1970 年代に入ってから合成開口レー ダーの開発が進んだ。現在では，干渉情報や偏波情報が同時に利 用できる NASA/JPL の AIRSAR や我が国の通信技術総合研究所 等が開発している PI-SAR 等があり，高精度な地形情報や地表の
物性の違いを明らかにする研究等が行われている5)。

\section{$2 \cdot 3$ 探査への適用}

変質鉱物は金属鉱床の成因に密接に関連していることが多く, その分布や鉱物の種類を把握することは鉱床探査上の重要な指針 となる。たとえば，斑岩型鉱床などでは鉱床の近傍から外側に向 かって特有の変質鉱物の組み合わせを持つ累帯構造を示すことが 多く，セリサイト，カオリナイト，モンモリロナイト，明樊石， 緑泥石，緑簾石などのような変質鉱物の識別が可能であれば変質 の累帯構造を推定することができる。一般的に変質鉱物は短波長 赤外域 (1.0 3.0 $\mu \mathrm{m}$ 付近) においてその化学的組成の違いにより 特徵的なスペクトルパターンを示す。このため，特に ASTERの 短波長赤外域にある 6 つのバンドを中心に利用することで従来で は不可能であった変質鉱物の種類の識別が可能になる。

金属鉱業事業団は 1996 年度から ASTER の実利用に備えるた めの研究開発を開始し, 2000 年度にはASTER 実画像が取得され たためこれを利用したケーススタディを行うとともに「金属鉱物 資源探査のための ASTER データ利用マニュアル」を作成した ${ }^{6}$ 。 特に金属鉱床の探査に重要な変質帯の識別の利用技術開発におい ては, ASTERの高波長分解能を有効に活用するため, フォール スカラー画像，比演算画像，岩石・鉱物指標による画像，等粒子 モデル7）と呼ばれる鉱物粒子間の反射・吸収を考慮した半定量 的鉱物同定画像等を用いた岩石・鉱物識別の検討を行った。この 結果，鉱床の周辺部を取り巻く微弱な変質帯のマッピングや，変 質鉱物の組み合わせによる変質帯分類が可能であることがわかっ た。

金属鉱業事業団が国際協力事業団から委託を受け実施した資源 開発協力基礎調查では, 2002 年度に実施した 13 地域での調査の うち 10 地域で衛星画像解析を行なった。その内訳は光学センサー データの解析 6 件, マイクロ波センサー ( レーダー) データの解 析 5 件である。2001 ～ 2002 年度のアルゼンティン共和国におけ る調査では，ASTER 画像を用いて広域レベルから鉱床有望地を 選定するための変質帯抽出作業を実施した。調査地域はアルゼン ティン北西部の面積約 $100,000 \mathrm{~km}^{2}$ の範囲で，地形的には標高 3 , $500 \sim 5,000 \mathrm{~m}$ 前後の山岳地帯である。本地域は原生代末期から 第四紀までの地質で構成され, オルドビス系に伴うSEDEX 型 鈆・ 亜鉛鉱床および新第三紀火山岩類に伴う斑岩型銅・金鉱床が胚胎 する。ASTER 画像から変質帯を抽出した結果に基づき現地検証 を行ったところ，既知鉱床・鉱徵地に伴う変質帯のほとんどが網 羅されていること，また，断層等に伴う微弱な粘土化帯等も抽出 されることがわかった。さらに，地表が植生で $30 \%$ 程度覆われ ていても，土㙵 (変質鉱物) の情報が取り出せることがわかった。 また，立体視画像を利用して作成した DEM (Digital Elevation Model) による高精度な地形図は, 良質な地形図のない遠隔地で の調査に極めて有益であった ${ }^{8)}$ 。

金属鉱業事業団は上記とは別に 1999 年度より海外衛星画像解 析調查を開始した。ユーラシア変動帯地域,インドシナ・マレー 地域, テチス海収束地域において, 衛星画像解析, グランドトルー ス，有望地抽出の作業を行い，探查プロジェクト形成の準備を進 めている。Fig.1 にイラン・イスラム共和国 北西部地域における 衛星画像解析結果の例を示す。

今後, ハイパースペクトルや高分解能センサーなどの高性能セ ンサーの適用を考えると，探査の初期段階だけではなく，よりス テージの進んだ状況での利用, たとえば精密な調查ルートの選定, ボーリングサイトの決定, 鉱山開発あるいは鉱山の環境モニタリ ング等の環境分野での利用が拡大していくものと思われる。一方, データ処理が容易でかつ信頼性の高い LANDSAT TM・ETM+や 


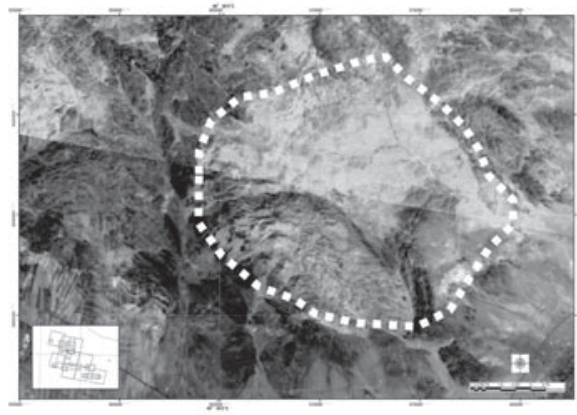

(a) FCC image (BGR=346)

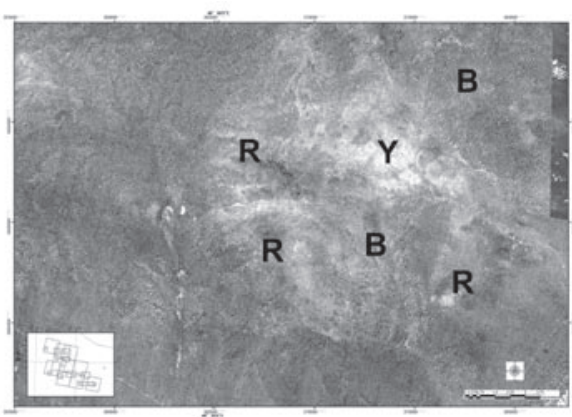

(b) Ratio image

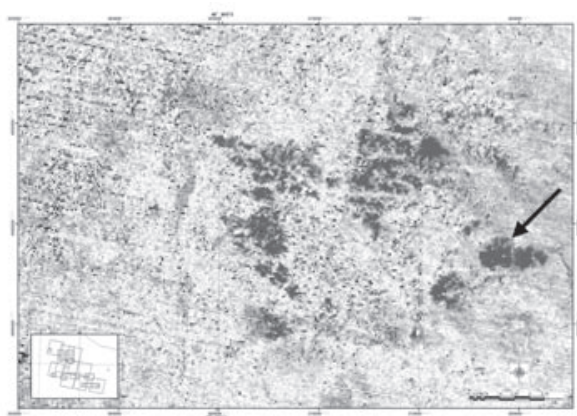

(c) $\mathrm{SiO}_{2}$ content index image

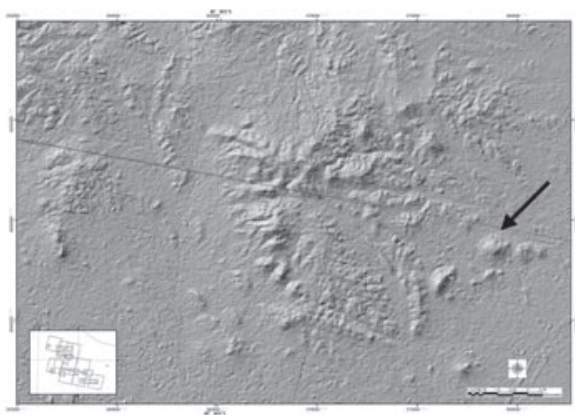

(d) DEM shade image

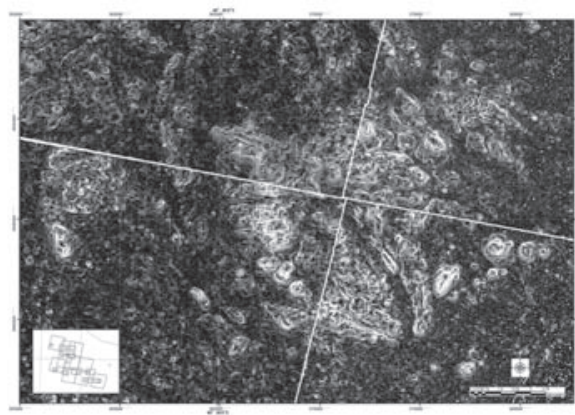

(e) DEM slope image (a) フォールスカラー画像 $(B G R=346)$ : 変質帯 (特に酸性変質带) は $\mathrm{BGR}=346$ のフォールスカラー画像では淡緑色〜青緑色に呈して見 える(破線で囲んだ付近)。

(b) 比演算画像 $(B G R=5 / 8,5 / 6,4 / 6)$ : この画像は ASTER バンド $5 / 8$ をP Propylitic 変質帯にバンド5/6を Phyllic 帯に，またバンド4/6を Advanced argillic 帯として代表させるもので, 酸性変質帯を伴うよ うな斑岩型鉱化帯に認められる変質帯が中心から外周に向けて赤色 $(\mathrm{R}) \rightarrow$ 黄色 $(\mathrm{Y}) \rightarrow$ 青色 (B) で示される (図中の R, B, Y で示寸付近)。

(c) $\mathrm{SiO}_{2}$ 含有量指標画像 : 二宮・傅 ${ }^{9)}$ は, 酸性岩ではバンド $13 ・ 14$ に おいて放射率が高くなり，超塩基性岩ではバンド $10 \sim 12$ に相当す る短波長域において黒体に近い放射特性になることに着目し, $\mathrm{SiO}_{2}$ 含有量指標 $\mathrm{SI}$ を提唱した $(\mathrm{SI}=$ バンド 13 / バンド 12$)$ 。本画像上て は矢印に示すような地域が珪化を受けている部分であり濃い色調と して示されている。

(d) 陰影画像 ( 太陽方向 315, 太陽高度 $\left.35^{\circ}\right)$ ：陰影画像は光源を用い て地形の陰影をつけることで立体的に地形を表現する手法であり, DEM を利用することでその光源の方向・角度を自由に設定するこ とができる。本地域は珪化が強い地域はピークを形成していること が多く ( 矢印等 $),$ 陰影画像でその地形的特徵が把握できる。

(e) 傾斜量画像 : 傾斜量画像は，特定の距離における(ここではピク セルサイズ) 標高の変化を計算し画像にしたものである。傾斜量画 像では傾斜の同じ領域が同じ濃度の画像として示され，地形の変化 を画像の濃淡で示寸ことができるため地形の不連続面の推定に利用 できる。陰影画像, $\mathrm{SiO}_{2}$ 含有量指標画像, フォールスカラー画像, 既存地質図等と併せて傾斜量画像を判読することでより明瞭に断裂 系の推定が可能になる。

Fig.1 イラン・イスラム共和国北西部地域 (Takestan 北東) における ASTER 画像解析例。スケールは東西約 $28 \mathrm{~km} \times$ 南北約 $24 \mathrm{~km} 。$ 
ASTERのような従来型の多バンドセンサーも，広域的な検討を 行うには重要であり, 引き続き多くの需要が見込まれると考えら れる。

\section{3. 物 理 探査}

物理探査の適用は，鉱床胚胎と関係する地質構造把握を目的と する場合 (概查) と潜頭性鉱床の捕捉や鉱床の深部への連続の確 認を目的とする場合 (精查) に分かれる。鉱山坑内の坑道やボー リング孔を利用して鉱量評価に役立てようという試みも続けられ ている。物理探查の特長は, 鉱床探查の概查から精查の流れに即 して空中探査・地上探査・ボーリング孔利用探查とバリエーショ ンが変えられること, また, 対象となる地質構造や鉱床タイプに 応じて種々の手法から適切な方法を選択できること, が挙げられ る。

物理探査の技術開発は大手鉱山会社, 物理探査コントラクター, 大学, 国立研究所などで行なわれている。北米では政府関係機関, 大学コンソーシアム, 物理探査コントラクターがその主体を担い 10), 豪州では AMIRA (Australian Mineral Industries Research Association Limited) や CRC (Cooperative Research Center)のような 組織が CSIRO, 大学, 鉱山会社などの研究開発を統括している 11）。以下に，手法別に最近の技術開発状況を概観する。

\section{3・ 1 重力探査}

重力探査は, 抽出された重力異常が鉱床そのものに起因し発見に 結びついた例もあるが (ポルトガル Neves Corvo 鉱床 - VMS 型 鉛・ 亜鉛鉱床- $\left.{ }^{12}\right)$ ), 通常は基盤構造などの地質構造把握を目的とし て広域的に行われる。これまでは地上探査のみであったが, 鉱床 探查への適用を目的とした空中重力探查の技術開発が 1990 年代 初頭より複数の組織で行われ, 近年実用化の段階に入った。 Falcon System は 1970〜80 年代に Bell Aerospace 社が開発した重 力偏差測定器を基に BHP 社が Lockeed Martin 社と共同で開発し たもので, 1990 年代後半からケーススタディを積んできた ${ }^{13)}$ 。 豪州 Cannington 鉱床 (SEDEX 型 銀・鉛・亜鉛鉱床) でのケース スタディでは，対地高度 $120 \mathrm{~m}$ のデータから鉱床と関係する重力 異常を抽出している。ここでの地形補正は, レーザー・スキャナー で取得した高分解能 DEM データから重力傾度をフォーワード計 算することにより求めている ${ }^{14)}$ 。コストは地上重力探查の 25 ～ $100 \%$ とのことから, 遠隔地等で地上探査にとって替わられる場 合も増えると予想される。

\section{$3 \cdot 2$ 磁気探査}

磁気探査はそのかなりの割合が空中磁気探査である。鉱床その ものに起因する磁気異常を直接抽出する場合もあるが ( 豪州 Cannnington 鉱床 ${ }^{15)}$ ), 広域的地質構造の把握に今や欠かせない 手法となっている。空中磁気探査は 1980 年代に大きく技術発展 したが, 技術開発要素として, 磁気センサーの感度向上・GPS による位置精度の向上・密な飛行測線間隔と低飛行高度による データの質の向上・画像処理技術の進歩による表示の改良, 等が 挙げられる。K-vapor 磁力計の開発, GPS による位置決め精度の 向上, microleveling, 低緯度地域における極磁気変換, gridding 手法の進歩, 3 次元逆解析など, この 10 年間にもハードからソ フトまで地道な技術開発が継続している ${ }^{10)}$ 。地形が平坦なとこ ろでは飛行測線間隔が数十 $\mathrm{m}$ の密な測定も行われ, 地上磁気探 查よりも優れているとの考えもある ${ }^{16)}$ 。現在は, データ取得・ 処理・解析技術の進歩に解釈技術が追いつかない状態にあり, 今 後の課題である。

金属鉱業事業団の資源開発協力基礎調査では, 1997 ～ 2001 年 度の 5 年間でフィリピン, チリ, マリ，モンゴル，ウルグアイの
各プロジェクトで空中磁気・放射能探查を行った。Fig.2 にモン ゴル国・西部エルデネット地域における空中磁気・放射能探査結 果を示す 17)。

\section{$3 \cdot 3$ 電磁探査}

$3 \cdot 3 \cdot 1$ 空中電磁探査豪州では, それまで困難であっ た導電性表層 (レゴリス ) 下に潜頭する鉱床を抽出するための研 究開発が行なわれ, 固定翼航空機を用いた時間領域の新システム が開発された。解析では時間領域, 周波数領域ともにデータを CDI (Conductivity-depth images) に変換する方法が実用化した。金 属鉱業事業団は 2002 年度モロッコ王国での資源開発協力基礎調 査で GEOTEM システム (時間領域) を使った空中電磁探査を実 施した。

3 $3 \cdot 2$ 地上電磁探査地上電磁探査は導電性鉱床の抽 出に威力を発揮し, 特に時間領域電磁探査 (TEM (Transient Elecromagnetic) 法 ) は VMS 型鉱床の探査にルーティン的に用い られる。TEM 法では, full-waveform のデータ記録と複数受信機 による多点測定の方向一展開している ${ }^{10)}$ 。解析技術は 2 次元・3 次元逆解析の研究が盛んであるが, まだ実用化レベルには至って いない。

高感度の超伝導磁力計 (SQUID 磁力計) を電磁探査に応用する 試みが国内外でなされてきている。従来の時間領域電磁探査は, 誘導コイルを受信センサーとして用い磁場の時間微分 $(\mathrm{dB} / \mathrm{dt})$ を 測定しているが，磁場そのもの (B field) を測定した方が探查深度 の点では優れている。SQUID 磁力計は B field を高精度で測定で き, 可探深度の増大が期待される。BHP 社 -CSIRO のグループは, SQUID 磁力計の空中電磁探査への適用を目指した研究を実施し た ${ }^{18)}$ 。一方, 金属鉱業事業団は地上電磁探査 (TEM 法) のシス テム開発を行っている 19)。

電磁探查のもう一つの手法である CSAMT (Controlled Source Audio-Magnetotelluric) 法は, MT (Magnetotelluric) 法では扱わない 高周波域 $(4 \mathrm{~Hz} \sim 8 \mathrm{kHz})$ を人工送信源でカバーした方法で 1980 年 代以降広く普及した。最近カナダで, 人工送信源なしで数百 $\mathrm{Hz}$ 以上の自然電磁場も利用するAMT (Audio-Magnetotelluric) 法が CSAMT 法に代わって用いられるようになってきた ${ }^{20)}$

\section{$3 \cdot 4$ 比抵抗 $/ I P$ 法電気探査}

電気探查のデータ取得は dipole-dipole 法が依然として主流であ るが, 解析では 2 次元逆解析がルーティン的に用いられるように なった ${ }^{21)}$ 。鉱床に起因する IP 異常の位置 (水平・垂直方向 ) の 精度を格段に上げ, 斑岩型鉱床や VMS 型鉱床の探查でボーリン グの位置・掘進深度の決定に貢献している。

\section{$3 \cdot 5$ 地震探査}

これまで地震探査反射法は鉱床探査にあまり用いられていな かったが，石油探鉱で発達した 3 次元のデータ取得・処理技術が， 地質構造が複雑な所の鉱床にうまく適用されているという報告が ある 10) (カナダ Thomson nickel belt, 南アフリカ共和国 Witwatersrand 鉱床地带)。

\section{$3 \cdot 6$ 放射能探査}

放射能探查は，空中磁気探査と併用されることが多い。0〜 $3000 \mathrm{keV}$ のエネルギー範囲で 256 channel のスペクトルデータ取 得が一般的となり, スペクトル解析における多チャンネル・スペ クトルのノイズ除去に進歩が見られた ${ }^{10)}$ 。

\section{$3 \cdot 7$ ボーリング孔利用物理探査}

ボーリング孔を利用する物理探査技術は, 検層, Down-hole EM，トモグラフィ，と多岐にわたるが，ボーリング孔周辺の物 性測定からはじまり経済的価值のある鉱体と周囲のズリとの境界 把握まで, 高分解能が要求される。鉱床探査や鉱山開発にルーティ 
(a)
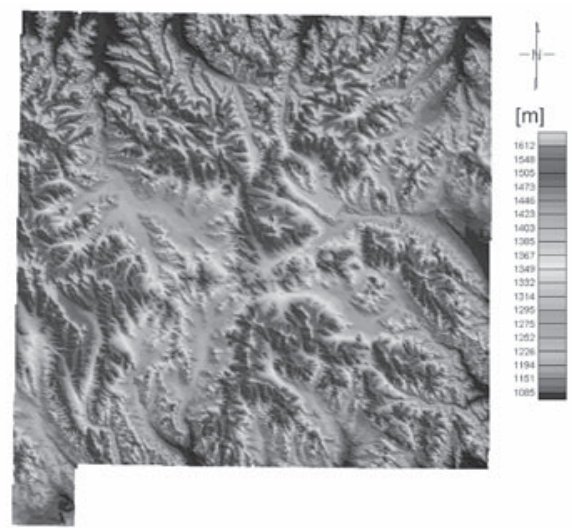

(b)
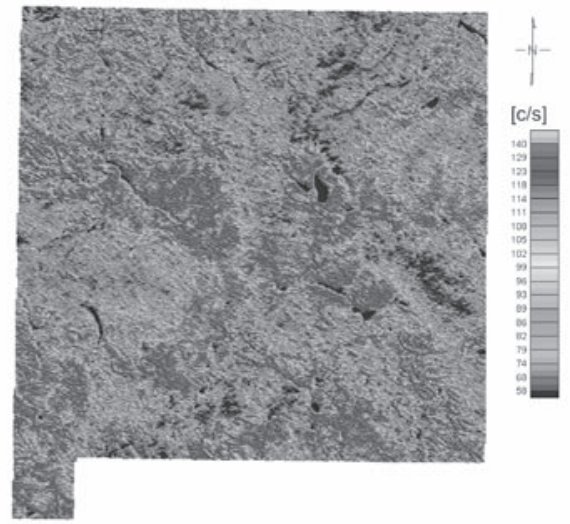

(c)

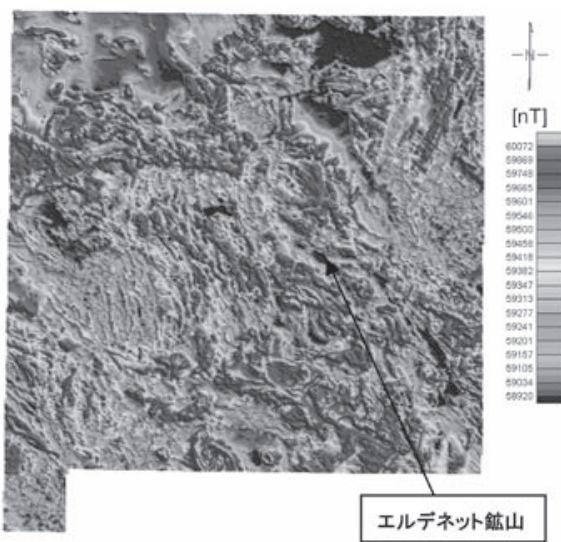

(d)

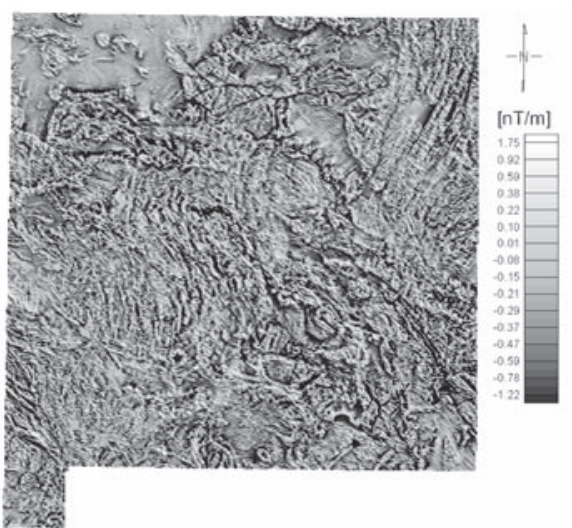

(a) デジタル地形図：GPS で測定された絶対高度と電波高度計で測定さ れた対地高度からから標高が求められる。既存地形図の品質・精度 が悪い地域では特に貴重なデータとなる。

(b) カリウム濃度図 : 空中放射能探査は，地表からその下 $50 \mathrm{~cm}$ 程度ま での間に分布する土畩や岩石の自然放射能を測定し，カリウム・卜 リウム・ウランの濃度が求まる。岩相区分やカリウムを含む変質帯 の抽出に優れている。本地域では, 高カリウム濃度は主として花崗 岩分布域と一致する。

(c) 全磁力図 (極磁気変換 ) : この地域のほぼ中央に東アジアで有数の 斑岩型 銅・モリブデン鉱床 (エルデネット鉱山 ) がある。この鉱床 は衛星鉱体とともに, NW-SE 方向に伸びる低磁気異常帯の中に位 置するが，これは鉱床を形成するエルデネット複合岩体の残留磁気 （逆帯磁），及び熱水変質作用による消磁の両方に起因寸ると考え られる。

(d) 全磁力・鉛直 1 次微分図（極磁気変換）: 鉛直 1 次微分図は全磁力 のグリッドデータを数值処理したもので，浅部の磁気異常を際立た せる効果を持つ。

Fig.2 モンゴル国・西部エルデネット地域における空中磁気・放射能探査結果。 固定翼航空機により対地高度 $120 \mathrm{~m}$ ，飛行測線間隔 $200 \mathrm{~m}$ で取得された測定值をグリッドデータに変換して表示している。 スケールは東西約 $70 \mathrm{~km} \times$ 南北約 $70 \mathrm{~km}$ 。 
ン的に組み込むための地道な試みがなされている 22)。

金属鉱業事業団では 1990 年代にボーリング孔利用物理探査の 技術開発を行い比抵抗卜モグラフィ, IP トモグラフィ, 電磁卜 モグラフィに取り組んだが ${ }^{23)}$, 実用化のためには更に多くのケー ススタディを積む必要がある。

\section{4. 地化学探査}

地化学探査は, 鉱床生成に伴う地化学異常 1 次八ローが鉱床周囲 に分布し, また鉱床の風化過程に伴う地化学異常の 2 次分散がし ばしば起こる，という事実を利用したものである。手法は分析対 象別に分けられ, 岩石・土壤・水河砕屑物・沢砂 (河床堆積物 )

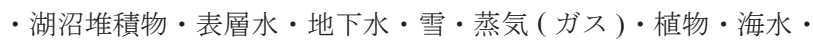
海底堆積物，等多岐に亘る 24$)$ 。これらうち陸上の鉱床探查と してルーティンとして用いられているのは, 岩石・土壌・沢砂地 化学探査である。

\section{4- 1 岩石地化学探査}

岩石地化学探査は, その異常を直接のターゲットとする場合も あるが，鉱床生成のメカニズムを考察する上で不可欠であり，結 果としてそれが鉱床探査に結びついている。カナダでは岩石の生 成〜鉱化変質過程解明に多元素解析を適用する研究がカナダ・ブ リティッシュコロンビア大学の MDRU (Mineral Deposit Research Unit）を中心に 1980 年代後半より活発になった。これは，熱水変 質や広域変成作用によって影響を受けない元素と影響を受ける元 素を識別し，両者の挙動を解析することにより鉱床生成に伴う物 質移動過程を解明しょうとするもので (Lithogeochemical technique), 熱水変質などを受けて複雑化した火山性塊状硫化物 鉱床の胚胎火山層序の復元などに利用されている ${ }^{25)}$ 。そのほか, 類似した手法として岩石系のある 2 つ元素量の比を利用して物 質移動過程を解明しようとする PER (Pearce Element Ratio) Approach ${ }^{26)}$ などもあり, これらの手法は現在もカナダを中心に 研究や実探査での利用 27$)$ が進められている。

\section{2 土袞地化学探査}

露頭の乏しいところでは, 必然的に土袞地化学探査に頼らざる を得ない。従来の土壌地化探が鉱床発見に繫がった例として，豪 州 Queensland 州 Century 鉱床 (SEDEX 型亜鋁・鉛) が挙げられる。 土壤試料は地表下 $10 \sim 30 \mathrm{~cm}$ の B 層から採取され, 混合酸で処 理した後ICP-OESで分析された。その結果得られた Zn 異常 (>1000 ppm)の直下に鉱床が胚胎していた ${ }^{28)}$ 。

1990 年代になると，土壌表面に吸着している元素，あるいは 土壌中の有機物に含まれている元素を選択的に抽出し分析する方 法が，豪州やカナダで研究された。これは旧ソ連邦で開発された 技術から出発しており，MMI 法あるいはEnzyme reach 法などと 呼ばれている 29)。金属鉱業事業団では MMI 法を菱刈鉱山の本 鉱床と山田鉱床の上で試験し，従来の土袞のバルク分析結果と比 較した。その結果, 複数の元素を解析すれば, 従来法よりも地化 学異常を明瞭に抽出できるとの結論を得ている ${ }^{30)}$ 。

カナダ CAMIRO (Canadian Mining Industry Research Organization) が 26 社のコンソーシアムをスポンサーとして実施したプロジェ クト ${ }^{31)}$ は, 選択的抽出法の発展形として興味深い。チリ第 II 州 の Spence 鉱床及び Gaby Sur 鉱床 (斑岩銅・金鉱床) を対象とし た試験調查では, 鉱床上位の崖錐堆積物を 5 種類の選択的抽出法 により処理・分析した結果, 鉱床直上及び付近の断裂帯の上で $\mathrm{Cu}, \mathrm{NaCl}, \mathrm{As}$ といった関係元素の濃度が高くなった。この地化 学異常形成の成因を, “関係元素を溶かし込んだ鉱床付近の地下 水が地震により地表付近まで上昇し, そこで元素を土壌中に沈殿 させた。複数回の地震が元素の一層の濃集をもたらした。”結
論している ${ }^{31)}$ 。その後の降雨などにより元素の垂直的再移動が 起こっており，試料採取レベルも重要である。

\section{$4 \cdot 3$ レゴリス・マッピング}

レゴリスとは風化を受けていない新鮮な岩石より上位に分布す るすべての岩石を指す用語で，土㙥もその構成メンバーの一つと なる。豪州では研究開発コンソーシアム CRC LEME (Cooperative Research Center for Landscape Environments and Mineral Exploration) が 1990 年代初頭に組織され，レゴリスの成因・分類・地化学異 常形成等の研究に取り組んでおり，その下位の鉱床探查に役立て ようとしている ${ }^{32,33)}$ 。

金属鉱業事業団は $2000 ２ 003$ 年度にマリ共和国において資源 開発協力基礎調查を実施したが, 調査地域 (バオレ・バニフィン グ地域 )には原生代の火山岩類・堆積岩類起源のグリーンストー ン(ビリミア累層群) が分布し，これに胚胎する金鉱床が探查対 象である。既に発見・開発されている金鉱床として Syama, Sadiola, Morila 等がある。地表はラテライト質風化帯が卓越し, 多様なレゴリス物質が分布する。これまで起源や風化程度の異な るレゴリス物質を規格化することなく評価し，高濃度で大規模な 地化学異常帯をボーリングの対象としていたため, 地化学異常の 下位に鉱化作用が続かないことが多かった。そこで 2002 年度よ りレゴリス地質学の考えを導入し,レゴリス図の作成を開始した。 その結果, 本地域のレゴリス種と分布及びラテライト質風化に起 因する元素の挙動が明らかとなり, 精查地区抽出手順として (1) $\mathrm{Au}$ 異常域の抽出 $\rightarrow$ (2) $\mathrm{As} / \mathrm{V}$ 元素濃度比異常域の抽出 (As の挙動は ラテライト性風化の過程で $\mathrm{Fe}$ 及び $\mathrm{V}$ と密接な関係を示すため, As と V の元素濃度比により鉱化作用起源の As 濃集の程度を評 価する ) $\rightarrow$ (3)レゴリス図との重社合わせによる原地性異常域の把 握，が妥当であるとの結論を得ている ${ }^{34)}$ (Fig.3)。

\section{$4 \cdot 4$ 沢砂地化学探査}

河川流域が発達する地域では沢砂地化学探査が用いられるが, この手法が鉱床発見に繋がった例としてインドネシア共和国スン バワ島の Batu Hijau 鉱床 (斑岩銅・金鉱床) が挙げられる ${ }^{35)} 。$ 1986 年の初期の調查ではー 40 メッシュ試料, - 80 メッシュ試 料及び水穊重鉱物と転石が同時に採取され, BLEG 法での Au 10 $\mathrm{ppb}$ 及び $15.3 \mathrm{ppb},-80$ メッシュ試料での $\mathrm{Cu} 135 \mathrm{ppm}$ の各異常 が注目された。1989 年のフォローアップ調査では, 発見露頭の 1 $\mathrm{km}$ 北の沢において BLEG 法で Au $169 \mathrm{ppb} ，-80$ メッシュ試料 で $\mathrm{Cu} 580 \mathrm{ppm}$ の異常が抽出された。

Fletcher ${ }^{36)}$ は沢砂地化学探查を行う場合の留意点として (1) 堆 積物は集水域を代表しているか，そうでなければ別の媒体を分析 対象とする必要がある，(2) 調査フィールドのどこで (あるいはい つ) 堆積物を採取すべきか，(3) 堆積物のどの粒度を分析す心゙き か，(4) 金のような非常に稀な重鉱物粒子を代表させるためには, 調査フィールドをどの程度大きく設定し，試料をどの程度多く採 取するか，を挙げている。

金属鉱業事業団は2001 2003 年度にインドネシア共和国東 ジャワで資源開発協力基礎調查を実施した。探査対象は斑岩銅・ 金鉱床及び浅熱水性金鉱床である。その一環として 2002 年度に $800 \mathrm{kn}^{2}$ の範囲において沢砂地化学探査を実施した ${ }^{37)}$ 。合計 519 個の試料を採取し, 採取密度は 0.6 個 $/ \mathrm{km}^{2}$ である。一 -80 メッシュ 試料とー 166 メッシュ試料を $\mathrm{Cu}$ と $\mathrm{Au}$ の分析值で比較した結果, - 166 メッシュ試料の方が再現性が高く, より高精度の地化学異 常を抽出可能である。また, 後背地の地質に応じて地化学高異常 の閾值を設定する必要性も指摘された。 
(a)

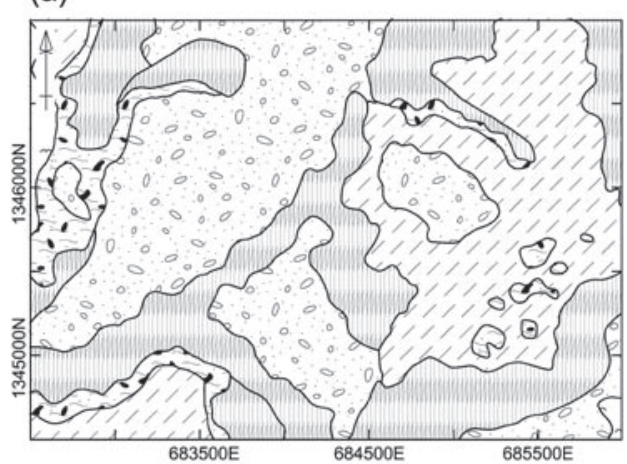

(b)

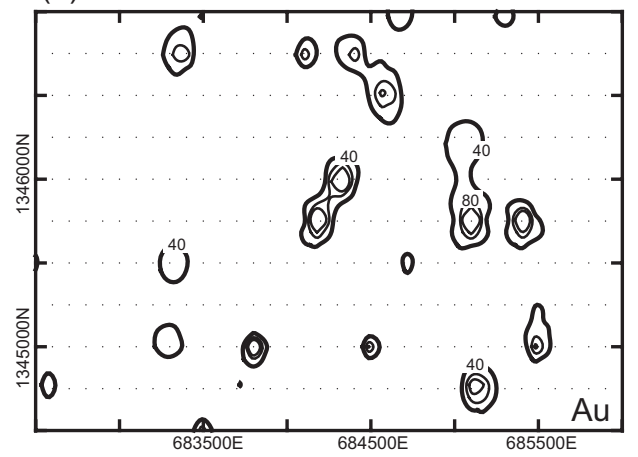

(a)レゴリスー地形図：浸食性領域が原地性レゴリス分布域に当た る。

\section{浸食性領域}

-1 斑紋带, 急㾏 悢紏面

サプロライト,小起状地

堆積領域性

フェリクリート,悢紏面

$\therefore$ 前辕土, 崩積地

沖皘層, 河床

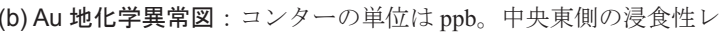
ゴリス上に地化学アノマリが把握されている。

(c)

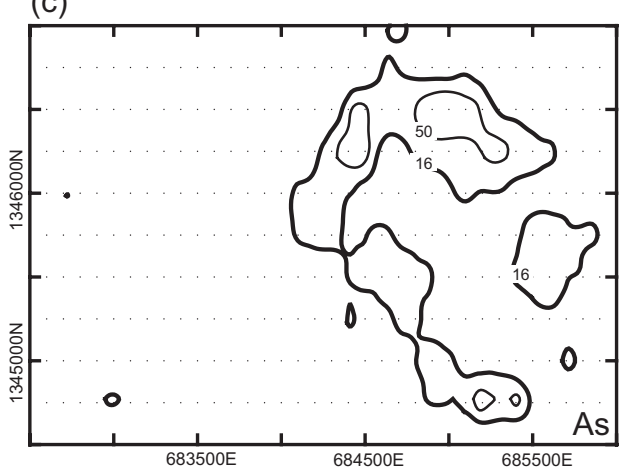

(d)

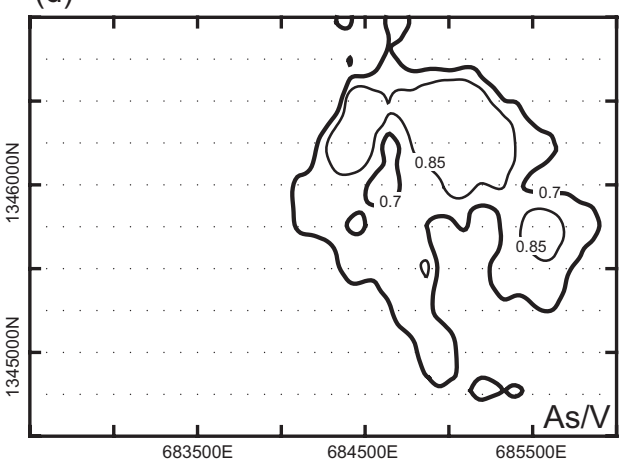

(c) As 地化学異常図 : コンターの単位は $\mathrm{ppm}_{0}$ 西側のフェリクリ 一ト（Fe の濃集する堆積性レゴリス）を中心に高アノマリとな っている。 (d) As/V 地化学異常図 : (c) のアノマリと比較しサプロライト分布 域上にも高いアノマリが得られ, 金鉱化作用由来の As 濃集と 判断される。一方で南側のフェリクリート上のAsアノマリは 縮小し, 風化作用由来の As 濃集であることを示している。

Fig.3 マリ共和国バオレ・バニフィング地域 レゴリス地形図と土壌地化学異常図 (縫部ほか34) 一部改変)

(a)〜 (d) の図面を重放合わせ, 原地性レゴリス上の $\mathrm{Au}, \mathrm{As} / \mathrm{V}$ 地化学異常域をターゲットとして精査地域を抽出した。 メモリはUTM 座標(WGS84)。 


\section{5. まとめ}

リモートセンシング, 物理探査, 地化学探查の技術は, ここ 10 年で様々なものが開発され，あるものは実用化されている。 GIS 解析もルーティン化し, 多種類かつ多量のデータを統合し, 探査結果を効率的に評価するのに大きく貢献している。

探査マネージャーは，自身の専門に拘らず，これら多様な技術 の適用性を理解し，探査ステージ・対象地域・鉱床タイプに応じ た適切な手法を取り入れなければならない。それまでの探査結果 を正しく評価し, 次の探査にフィードバックすることも重要であ る。

謝辞＼cjkstart本総説について適切なコメントをいただいた匿名の査読 者に感謝いたします。

\section{References}

1) 資源・環境観測解析センター: 宇宙からの地球観測, 資源・環境リモートセン シング実用シリーズ 1(2001), p. 275

2）資源・環境観測解析センター: ScanSARーインターフェロメエトリー処理找 術の研究開発, 平成 9 年度石油資源遠隔探知技術の研究開発報告書 (1997a), $3 / 5$, pp. 65-101.

3）資源・環境観測解析センター: レーダーポラリメトリの応用に関寸る研究，平 成 9 年度石油資源遠隔探知技術の研究開発報告書 (1997b), 3/5, pp.35-64

4) T. Cudahy, M. Wells, R. Hewson, A. Cornelius and T. Yajima: Spectralphysicochemicasl characterization and remote mapping of gossans from the $\mathrm{Cu}-\mathrm{Zn}-\mathrm{Pb}$ Panorama VMS-magmatic system, Pilbara, Western Australia. CSIRO Exploration and Mining Report 915R(2002), pp.1-43.

5) 梅原俊彦・前野英生・佐竹誠・浦塚清峰: 航空機搭載 SAR(Pi-SAR) 再生画 像の位置精度評価, 日本リモートセンシング学会第 31 回学術講演論文集 P-56(2001), pp.267-268

6) 大岡隆・小島和浩・増田信行・広瀬知世 : ASTER データ利用技術の開発,資源 地質, 52(2002), 45-49.

7) T. Hiroi and H. Takeda: A Method to determine silicate abundances from reflectance spectra with applications to asteroid 29 Amphitrite associating it with primitive achondrite meteorites, Icarus, 88(1990), 205-227.

8）国際協力事業団・金属鉱業事業団: 平成 $13 \cdot 14$ 資源開発協力基礎調查報告書 アルゼンティン共和国 北西部地域 $(2002,2003)$ p.346, p.333.

9）二宮芳樹・傳碧 宏：ASTER 熱赤外データのバンド間演算による石英指標，岸 酸塩鉱物指標, および $\mathrm{SiO} 2$ 含有量指標, 日本リモートセンシング学会誌, 22(2002), 50-61

10) M. Nabighian, and M. Asten: Metalliferous mining geophysics -State of the art in the last decade of the 20th century and the beginning of the new millennium, Geophysics, 67(2002), 964-978.

11）岡田和也: オーストラリアにおける金属資源開発と物理探査技術を取り巻く状 況, 物理探査, 54(2001), 315-327.

12) J. Relvas et al. The Neves-Corvo deposit, Iberian pyrite belt, Portugal: Impacts and future, 25 years after the discovery. In Integrated methods for discovery: Global exploration in the twenty-first century. Econ. Geol. Special Publication 9(2002) 155-176.

13) E. Van Leeuwe: BHP develops airborne gravity gradiometer for mineral exploration, The Leading Edge, 19(2000), 1296-1297.

14) A. Christensen, A. Mahanta, D. Bboggs and M. Dransfield: Falcon airborne gravity gradiometer survey results over the Cannington Ag-Pb-Zn deposit, ASEG 15th Geophysical Conference and Exhibition(2001), Brisbane.

15) S. Walters et al.: Discovery and geology of the Cannington Ag-Pb-Zn deposit, Mount
Isa eastern succession, Australia: Development and application of an exploration mode for Broken Hill-type deposits. In Integrated methods for discovery: Global exploration in the twenty-first century. Econ. Geol. Special Publication 9(2002), 95-118.

16) P. Basford and N. Hughes: A comparison of high density ground magnetic surveys and low-level aerial magnetic surveys in a near-surface noise environment -A Cobar case history, ASEG Preview, 76(1998), 101.

17）国際協力事業団・金属鉱業事業団：平成 13 資源開発協力基礎調査報告書モン ゴル国 西部エルデネット地域 (2001) p.304.

18) J. Lee et al.: Airborne TEM surveying with a SQUID magnetometer sensor, Geophysics, 67(2002), 468-477.

19）荒井英一・片山弘行・小島和浩・増田信行：SQUID 磁力計を利用した高精度 電磁探査技術の開発, 資源地質, 52(2002), 1-9.

20) X. Garcia and A. Jones: Atmospheric sources for audio-magnetotelluric (AMT) sounding. Geophysics, 67(2002), 448-458.

21) Y. Sasaki: Automatic interpretation of induced polarization data over two-dimensional structures, Memoirs of the Faculty of Engineering, Kyushu University, 42(1986), 59-74.

22) P. Basford: Development of a short-term model using petrophysical logging at Century mine, North Queensland, ASEG Preview, 92(2001), 19-24.

23) E. Arai et al.: Application of IP and EM tomography systems for mineral exploration, Proceedings of the 4th international workshop on the application of geophysics to rock engineering, organized by the ISRM Commission on application of geophysics to rock engineering(2001), Beijing, pp. 1-7.

24) W. Peters: Exploration geochemistry and geobotany, In Exploration and mining geology. 2nd ed., John Wiley \& Sons,1987, pp.397-432.

25) W. MacLean and T. Barrett: Lithogeochemical techniques using immobile elements, J. Geochem. Explor., 48(1993), 109-133.

26) C. Stanley and H. Madeisky: Applications in lithogeochemical exploration. Minera Deposit Research Unit, Dept. of Geological Science, Univ. of British Columbia, Short course no.13 notes(1993), Vancouver, British Columbia

27) T. Barrett, W. Maclean and S. Tennant: Volcanic sequence and alteration at the Parys Mountain volcanic-hosted massive sulfide deposit, Wales, United Kingdom: Applications of Immobile element lithogeochemistry, Econ. Geol., 96(2001), 1279-1305.

28) G. Broadbent, S. Andrews and I. Kelso: A decade of new ideas: Geology and exploration history of the Century $\mathrm{Zn}-\mathrm{Pb}-\mathrm{Ag}$ deposit, Northwestern Queensland, Australia. In Integrated methods for discovery: Global exploration in the twenty-first century. Econ. Geol. Special Publication 9(2002), 119-140.

29) G. Hall: Analytical perspective on trace element species of interest in exploration. J. Geochem. Explor., 61(1998), 1-19.

30) 通商産業省・資源エネルギー庁：Mobile Metal Ion (MMI) soil geochemistry in the Hokusatsu-Kyushikino region Honko and Yamada deposits, Hishikari mine. 平成 9 年 度広域地質構造調查報告書 北薩・串木野地域 (1998), pp.49-95

31) E. Cameron, M. Leybourne and D. Kelley: Exploring for deeply covered mineral deposits: Formation of geochemical anomalies in northern Chile by earthquakeinduced surface of mineralized groundwaters, Geology, 30(2002), 1007-1010.

32) G. Taylor and C. Butt: The Australian regolith and mineral exploration. In AGSO Journal of Australian Geology and Geophysics.17(1998), 55-67.

33) 縫部保徳：レゴリス地質学々地化学探査,資源地質, 54(2004), 91-99.

34) 縫部保徳・甲斐道照・鈴木満・長尾尚顕・武山眞 : マリ共和国バオレ・バニフィ ング地域の金鉱床探査とその成果ーレゴリス地質に基づく地化学探査データの 評価一, 資源地質, 54(2004), 37-46.

35) R. Sillitoe: Exploration and discovery of base- and precious-metal deposits in the circum-Pacific region during the last 25 years, Metal Mining Agency of Japan(1995) p.127.

36) W. Fletcher: Stream sediment geochemistry in today's exploration world. In Gubins, A.G. (ed), Geophysics and geochemistry at the millennium. Proceedings of Exploration 97: 4th Decennial Int. Conf. Mineral Exploration. Prospectors and Developers Association of Canada, Toronto, 1997, pp. 249-259.

37) 山本耕次・鈴木哲夫・三宅一弘 : 熱帯地域における沢砂地化学探査の手法と解 析ーインドネシア共和国東ジャワ地域の例一,資源地質, 53(2003), 19-28. 